\title{
FORECASTING THE RISIK OF COMBINED EFFECT OF AVERMECTIN AND NEONICOTINOID INSECTICIDES ON WORIKERS
}

\author{
Yastrub T. A., Dontsova D. A.
}

State Institution «Kundiiev Institute of Occupational Health of the National Academy of Medical Sciences of Ukraine», Kyiv

Introduction. To prevent the development of resistance mechanisms and to improve the biological efficacy of pesticides in plant protection systems, there is a trend towards an increasing number of complex mixtures of pesticide formulations containing two or more active ingredients, increasing the likelihood of their hazardous effects on workers. Therefore, identification of potential and real hazards of combined pesticides is an urgent task of preventive toxicology and occupational medicine.

The aim of the study was to predict the risk of occupational combined exposure to emamectin benzoate and acetamiprid when using a mixture composition based on them to protect sunflower and corn crops.

Materials and methods of the research. Expert analytical study of scientific information on the toxicological properties of emamectin benzoate and acetamiprid, methods of toxicological experiment on laboratory animals, the predictive model of risk assessment, the Finney method to account for combined effects of pesticides on workers. Results. By the example of mixed pesticide composition based on insecticides emamectin benzoate (chemical class of compounds - avermectins) and acetamiprid (chemical class of compounds - neonicotinoids) it was found that the combined effect of these substances was characterized by a well-defined effect of potentiation. The potency factor, which for a particular mixture of these substances is 3.12, was taken into account in hazard identification using a predictive risk assessment model. It was found that the risk of cumulative inhalation exposure exceeded the acceptable level, indicating the need for appropriate management decisions.

Conclusions. The prospect of combinations of active substances in pesticide formulations carries a threat of possible potentiation as one of the most dangerous types of combined exposure. The necessity of consideration of potentiation coefficients at study of working conditions with the use of combined preparations on the basis of active substances with the similar orientation of toxic effects is substantiated. It will raise accuracy and reliability of results of an estimation of professional risk and will promote development of preventive actions on the prevention of harmful influence of pesticides on an organism of workers.

Key words: mixed insecticide, emamectin benzoate, acetamiprid, toxicological and hygienic assessment, forecasting combined risk

\section{Introduction}

Worldwide experience in the use of pesticides shows the real danger of their harmful effects on the health of workers. The main classes of pesticides that can cause acute occupational intoxications are organochlorine, organophosphorus compounds, pyrethroids, neonicotinoids, which are widely used both in agriculture and as insecticides in households and household plots. Such poisonings cause long-term disability and result in significant socio-economic losses. For exam- ple, in the USA, such costs exceed 1000000000 dollars annually [1].

In Ukraine during 80s-90s agricultural sector took the $2-3$ places in the structure of occupational diseases, and it accounted for $20 \%$ of victims in the total structure of occupational diseases [2]. During last decades on the background of increasing volumes of plant protection products and increasing of agricultural production the dynamics of occupational disease rate in agriculture of Ukraine is characterized

(C) Collective of authors, 2021 
by significant decrease of number of victims from 151 in 2001 to 9 in 2017, its decrease from 0,37 to 0,02 to 10 thousand employees and significant decrease of specific weight of occupational diseases in agriculture in total number of occupational diseases annually registered in Ukraine (up to $0,3-0,5 \%$ ) [3].

The main reason of decrease of occupational morbidity level among agricultural workers is the fact that in most companies of agro-industrial complex, especially in small farms, up to $60-80 \%$ of employees are hired as seasonal workers (both from local villages, and from other regions of Ukraine) without legal registration at work and without prior medical examination, therefore, often - with contraindications to work with adverse production factors, especially pesticides, and the inability of confirming the occupational aetiology of the disease, due to the difficulty of obtaining sanitary and hygienic characteristics of working conditions.

Undoubtedly, the existing legislative and regulatory framework provides legal regulation of pesticide use in Ukraine, but requires continuous substantial modernisation and review, due to new challenges and demands of society. Restructuring of large agricultural enterprises, transfer of property and land into private ownership caused structural changes in production and redistribution of labour resources by branches, sub-branches of agricultural production. One of the peculiarities of this process is a big discrepancy in the number of actually employed in agricultural enterprises and those officially registered.

In this regard, the primary task of state authorities responsible for registration and control of pesticides is to implement high-quality postregistration monitoring aimed at risk-oriented approaches to assessment of the state of production and environment from pesticide use as a leading factor of agricultural production growth and global pollutants of agri-ecosystems biodiversity.

In recent years, the trend towards increasing the number of complex mixtures of pesticide formulations containing two or more active substances in order to prevent the development of resistance mechanisms and improve the biological efficacy of pesticides in plant protection systems has become particularly relevant. This, in its turn, increases the probability of hazardous effects of mixed pesticides on workers and requires consideration of the possible combined effect of several active ingredients [4]. Therefore, establishing the potential and real hazards of the effects of combined products on workers is an urgent task of preventive toxicology and occupational medicine.

On the example of mixed pesticide composition on the basis of insecticides emamectin benzoate (chemical class of compounds - avermectins) and acetamiprid (chemical class of compounds - neonicotinoids) the characterization of combined effect was carried out and the potential risk of their adverse effect on health of workers was estimated.

The purpose of the study is to predict the risk of occupational combined exposure to emamectin benzoate and acetamiprid when applying a mixture composition based on them to protect sunflower and corn crops.

\section{Materials and methods of research}

The objects of the study were the combined insecticide «Emipride, WG» (emamectin benzoate, $100 \mathrm{~g} / \mathrm{kg}+$ acetamiprid, $150 \mathrm{~g} / \mathrm{kg}$ ), exposure doses of emamectin benzoate and acetamiprid determined in toxicological experiments of different duration (scientific literature data) and in state tests of the insecticide on sunflower and corn crops using boom spraying.

The choice of this pesticide composition for predicting the risk of occupational combined 
exposure was dictated by the previous detailed review of scientific literature on the toxicological properties of emamectin benzoate and acetamiprid across different modes of their impact on an organism, including the long-term effects.

The methods of expert analytical study of scientific information on toxicological properties of emamectin benzoate and acetamiprid were used, as well as methods of toxicological experiment on laboratory animals (rats), prognostic model of risk assessment, Finney's method (1952) for accounting combined effect of pesticides on workers with estimation according to the «lethal effect» criteria which means determination of median lethal dose $\left(\mathrm{LD}_{50}\right)$ of each substance studied, its percentage in mixture, contribution of substance in $\mathrm{LD}_{50}$ of mixture and percentage of this amount of the substance's $\operatorname{LD}_{50}$ (Y. Kagan, 1981):

$$
\frac{\mathrm{A}}{\mathrm{LD}_{50(\mathrm{a})}} \cdot 100 \%+\frac{\mathrm{B}}{\mathrm{LD}_{50(\mathrm{~b})}} \cdot 100 \% \text {, }
$$

where $\mathrm{A}$ is the quantity of substance «a» (mg/ $\mathrm{kg}$ ) that contributes to the $\mathrm{LD}_{50}$ of the mixture;

$\mathrm{LD}_{50 \text { (a) }}$ - the average lethal dose of substance «a» $\mathrm{mg} / \mathrm{kg}$;

$\mathrm{B}-$ quantity of substance $\ll \mathrm{b} »(\mathrm{mg} / \mathrm{kg})$, contained in $\mathrm{LD}_{50}$ of the mixture;

$\mathrm{LD}_{50 \text { (b) }}$ - the average lethal dose of substance $\ll \mathrm{b} » \mathrm{mg} / \mathrm{kg}$.

Type of combined action (summation, antagonism, potentiation) was determined by sum of percentages obtained. If the sum of percentages is greater than 100 , i.e. in order to obtain lethal effect a dose of substances which in total exceeds $\mathrm{LD}_{50}$ is needed, the antagonism takes place. A sum of percentages less than 100 indicates a potentiation effect, a sum of percentages equal to 100 characterizes summation.

Toxicological studies on acute oral toxicity of Emipride, WG were conducted using OECD (Organisation for Economic Co-operation and
Development): Guideline for Testing of Chemical «Acute Oral Toxicity - Acute Toxic Class Method», No. 423. Toxicological studies adopted by the Bioethics Commission of the State Institution «Kundiiev Institute of Occupational Health of the National Academy of Medical Sciences of Ukraine» (protocol of 23.01.2019 No. 1).

A predictive exposure model (POEM) was used to predict and quantify levels of inhalation and percutaneous exposure to emamectin benzoate and acetamiprid to which the operator may be exposed at different stages of the process (preparation of working solutions, filling the technical equipment and spraying) [5]. General characteristics of emamectin benzoate and acetamiprid are given in the Table 1 .

\section{Results of research and discussion}

The toxicological profile of emamectin benzoate and acetamiprid is widely reported in the scientific literature [6-9]. The acute toxicity parameters and non-acting dose levels determined in short- and long-term experiments on laboratory animals (mice, rats, dogs), including distant effects of action, are given in Table 2 .

Emamectin benzoate, an insecticide of the avermectin class, causes neurotoxic effects that have been observed in acute, subchronic, chronic exposure regimes and developmental neurotoxicity studies. Signs of neurotoxicity included mydriasis, salivation, tremor, impaired movement coordination, limb stiffness, decreased feed intake and body weight gain.

The neurotoxic effects of emamectin benzoate are related to impaired function of gamma-aminobutyric acid (GABA), an amino acid that acts as a neurotransmitter in vertebrates and invertebrates. Emamectin benzoate, like other avermectins, binds to GABA receptors, resulting in increased chloride ion permeability in nerve and 
General characteristics of the active substances in question

\begin{tabular}{|c|c|c|}
\hline \multirow{2}{*}{ Indicator } & \multicolumn{2}{|l|}{ Active substance } \\
\hline & emamectin benzoate [6] & acetamiprid [7] \\
\hline $\begin{array}{l}\text { Chemical class } \\
\text { of compounds }\end{array}$ & $\begin{array}{l}\text { Avermectins. Mixture containing emamectin } \mathrm{B}_{1 \mathrm{a}}(\geq 90 \%) \text { and } \\
\text { emamectin } \mathrm{B}_{1 \mathrm{~b}}(\leq 10 \%) \text { in the form of emamectin benzoate }\end{array}$ & $\begin{array}{l}\text { Neonicotinoid insecticides } \\
\text { (chloronicotinyls) }\end{array}$ \\
\hline CASRN & $\begin{array}{l}{[155569-91-8]-\text { emamectin benzoate; }[138511-97-4]-\text { emamec- }} \\
\text { tin } \mathrm{B}_{1 \mathrm{a}} \text { benzoate; }[138511-98-5]-\text { emamectin } \mathrm{B}_{1 \mathrm{~b}} \text { benzoate }\end{array}$ & [135410-20-7] \\
\hline $\begin{array}{l}\text { Empirical } \\
\text { formula }\end{array}$ & $\begin{array}{l}\text { Emamectin } \mathrm{B}_{1 \mathrm{a}}: \mathrm{C}_{49} \mathrm{H}_{75} \mathrm{NO}_{13} ; \\
\text { emamectin } \mathrm{B}_{1 \mathrm{~b}}: \mathrm{C}_{48} \mathrm{H}_{73} \mathrm{NO}_{13} ; \\
\text { emamectin } \mathrm{B}_{1 \mathrm{a}} \text { benzoate: } \mathrm{C}_{56} \mathrm{H}_{81} \mathrm{NO}_{15} \text { або } \mathrm{C}_{49} \mathrm{H}_{75} \mathrm{NO}_{13} \cdot \mathrm{C}_{7} \mathrm{H}_{6} \mathrm{O}_{2} \text {; } \\
\text { emamectin } \mathrm{B}_{1 \mathrm{~b}} \text { benzoate: } \mathrm{C}_{55} \mathrm{H}_{79} \mathrm{NO}_{15} \text { або } \mathrm{C}_{48} \mathrm{H}_{73} \mathrm{NO}_{13} \cdot \mathrm{C}_{7} \mathrm{H}_{6} \mathrm{O}_{2}\end{array}$ & $\mathrm{C}_{10} \mathrm{H}_{11} \mathrm{ClN}_{4}$ \\
\hline $\begin{array}{l}\text { Relative mole- } \\
\text { cular weight }\end{array}$ & $\begin{array}{l}\left.886,1 \text { (emamectin } \mathrm{B}_{1 \mathrm{a}}\right) ; 872,1\left(\text { emamectin } \mathrm{B}_{1 \mathrm{~b}}\right) ; 1008,3 \text { (emamec- } \\
\text { tin } \mathrm{B}_{1 \mathrm{a}} \text { benzoate); } 994,2\left(\text { emamectin } \mathrm{B}_{1 \mathrm{~b}} \text { benzoate) }\right.\end{array}$ & 222,7 \\
\hline
\end{tabular}

muscle tissues by opening chloride channels. There is no specific antidote for the effect of emamectin benzoate on GABA receptors.

At the cellular level, emamectin benzoate causes degeneration of nerve axons in CNS and PNS, in some cases nerve tissue degeneration leads to degeneration of muscle tissue, which has been noted in acute and long-term experiments on mammals. The substance may be a specific toxicant to optic nerves and retinal tissue. Signs of neurotoxicity include mydriasis (dilated pupils), salivation, tremor, impaired coordination of movements, rigidity of limbs, reduced feed intake and body weight gain.

Acetamiprid is an insecticide from the class of heterocyclic compounds (pyridylmethylamine neonicotinoids), whose peculiarity is visocospecific (high biological effectiveness against insect pests and safety for honey bees). Unlike organophosphorus compounds, the mechanism of action of neonicotinoids is based on disruption of nerve impulse conduction due to formation of acetylcholine competitors, not degraded by acetylcholinesterase.

Acetamiprid is characterized by manifestations of neurotoxic action. Thus, according to the results of the toxicological assessment of acet- amiprid conducted by EFSA experts in 2016, the values of acceptable daily intake (ADI) and acceptable operator exposure level (AOEL) were revised downwards from $0.07 \mathrm{mg} / \mathrm{kg}$ to $0.025 \mathrm{mg} / \mathrm{kg}$ based on the results of neurotoxicity studies for progeny.

The foregoing suggests that a potentiation of their toxic effects is possible with co-exposure to emamectin benzoate and acetamiprid. Of course, it is difficult to assess the nature and type of combined action at threshold and non-effect doses on the prediction of chronic effects. Therefore, the combined effects were assessed using the $\mathrm{LD}_{50}$ values established for Emipride, WG and its active substances in an acute oral toxicity study.

Acute oral toxicity of Emipride, WG was studied in female Wistar Han rats using OECD Test Guideline No. 423 at doses of 300 and $2000 \mathrm{mg} /$ $\mathrm{kg}$ body weight, in stages starting with the lowest dose. When administering the drug at a dose of $300 \mathrm{mg} / \mathrm{kg}$ no animal death or clinical symptoms of intoxication were observed. At a higher dose, clinical signs of intoxication in the form of decreased motor activity, depression, narrowing of the eye slit, hunchbacked posture, respiratory disorders (dyspnea), in the terminal stage - lateral position, convulsions, coma were 
Results of toxicological studies on emamectin benzoate and acetamiprid

\begin{tabular}{|c|c|c|}
\hline \multirow{2}{*}{$\begin{array}{l}\text { Type of } \\
\text { research }\end{array}$} & \multicolumn{2}{|l|}{ Active substance } \\
\hline & emamectin benzoate $[6,8]$ & acetamiprid [7,9] \\
\hline $\begin{array}{l}\text { Acute oral } \\
\text { toxicity }\end{array}$ & $\begin{array}{l}\mathrm{LD}_{50} \text { for male rats }-67(54-84) \mathrm{mg} / \mathrm{kg} \\
\text { female rats }-70(55-104 \mathrm{mg} / \mathrm{kg})\end{array}$ & $\begin{array}{l}\mathrm{LD}_{50} \text { for rats of different lines (males, } \\
\text { females) }-140-417 \mathrm{mg} / \mathrm{kg}\end{array}$ \\
\hline $\begin{array}{l}\text { Subacute } \\
\text { oral toxicity }\end{array}$ & $\begin{array}{l}\text { Rats (male, female): } \\
\text { NOAEL* }-50 \mathrm{ppm}(5 \mathrm{mg} / \mathrm{kg})\end{array}$ & $\begin{array}{l}\text { Dogs: NOAEL - } 1000 \text { ppm } \\
(22-43 \mathrm{mg} / \mathrm{kg})\end{array}$ \\
\hline $\begin{array}{l}\text { Subchronic } \\
\text { oral toxicity }\end{array}$ & $\begin{array}{l}\text { NOAEL for male rats }-5 \mathrm{ppm}(0,5 \mathrm{мг} / \mathrm{кг}) \\
\text { female }-25 \mathrm{ppm}(2,5 \mathrm{mg} / \mathrm{kg}) \\
\text { NOAEL for mice (male, female })-5,5 \mathrm{mg} / \mathrm{kg}\end{array}$ & $\begin{array}{l}\text { NOEL** for rats }-200 \mathrm{ppm} \\
(12,4 / 14,6 \mathrm{mg} / \mathrm{kg}-\text { male/female, acc. }) \\
\text { NOEL for mice }-400 \mathrm{ppm} \\
(53,2 / 64,6 \mathrm{mg} / \mathrm{kg}-\text { male/female, acc. }) \\
\text { NOEL for dogs }-800 \mathrm{ppm} \\
(32 \mathrm{mg} / \mathrm{kg}-\text { male/female, acc. })\end{array}$ \\
\hline $\begin{array}{l}\text { Chronic } \\
\text { toxicity }\end{array}$ & $\begin{array}{l}\text { NOAEL for rats (male, female) }-1 \mathrm{mg} / \mathrm{kg} \text { (by neuro- } \\
\text { toxicity), } 0,25 \mathrm{mg} / \mathrm{kg} \text { (by the effect on body weight and } \\
\text { biochemical parameters of serum in females) } \\
\text { NOAEL for mice (male, female) }-9-20 \mathrm{ppm}(2,5 \mathrm{mg} / \mathrm{kg}) \\
\text { NOAEL for dogs }-0,25 \mathrm{mg} / \mathrm{kg} \text {, by clinical and histologi- } \\
\text { cal changes in the nervous system }\end{array}$ & $\begin{array}{l}\text { NOEL for rats }-160 \mathrm{ppm} \\
(7,1 / 8,8 \mathrm{mg} / \mathrm{kg}-\text { male/female, acc }) \\
\text { NOEL for mice }-130 \mathrm{ppm} \\
(20,3 / 25,2 \mathrm{мг} / \mathrm{К}-\text { male/female, acc. }) \\
\text { NOEL for dogs }-600 \mathrm{ppm} \\
(20 / 21 \mathrm{mg} / \mathrm{kg}-\text { male/female, acc })\end{array}$ \\
\hline $\begin{array}{l}\text { Teratogenic } \\
\text { and embryo- } \\
\text { toxic effects }\end{array}$ & $\begin{array}{l}\text { NOAEL for rats }-2 \mathrm{mg} / \mathrm{kg} \text { (by toxicity to the mother), } \\
\text { NOAEL (for posterity) }-4 \mathrm{mg} / \mathrm{kg} \\
\text { NOEL for rabbits }-3 \mathrm{mg} / \mathrm{kg} \text { (by toxicity to the mother), } \\
\text { NOEL }-6 \mathrm{mg} / \mathrm{kg} \text { (by the impact on development) }\end{array}$ & $\begin{array}{l}\text { NOEL for rats }-16 \mathrm{mg} / \mathrm{kg} \\
\text { NOEL for rabbits }-30 \mathrm{mg} / \mathrm{kg}\end{array}$ \\
\hline $\begin{array}{l}\text { Reproductive } \\
\text { toxicity }\end{array}$ & $\begin{array}{l}\text { NOAEL for rats }-0,6 \mathrm{mg} / \mathrm{kg} \text { (by toxicity to the mother, } \\
\text { toxicity to parental generations, offspring and reproduc- } \\
\text { tive toxicity) }\end{array}$ & $\begin{array}{l}\text { NOEL for rats by reproductive } \\
\text { function }-800 \mathrm{ppm} \text {, by systemic toxi- } \\
\text { city }-100 \mathrm{ppm} \text {, for neonatal develop- } \\
\text { ment }-280 \mathrm{ppm}\end{array}$ \\
\hline $\begin{array}{l}\text { Special } \\
\text { research }\end{array}$ & $\begin{array}{l}\text { Subchronic neurotoxicity: } \\
\text { NOEL for neurotoxic effects for male rats }-1 \mathrm{mg} / \mathrm{kg} \text {; } \\
\text { NOEL for female rats }-0.1 \mathrm{mg} / \mathrm{kg} \\
\text { NOEL for hounds }(14 \text { days of exposure) }-0.25 \mathrm{mg} / \mathrm{kg} \\
\text { (degenerative changes in the nervous system, optic nerve } \\
\text { damage at a dose of } 1 \mathrm{mg} / \mathrm{kg} \text { ) } \\
\text { Chronic neurotoxicity: NOEL for dogs on neurotoxic } \\
\text { effects }-0.5 \mathrm{mg} / \mathrm{kg} \text { (optic nerve damage) } \\
\text { Neurotoxicity for offspring development: } \\
\text { NOAEL for rats }-0,6 \mathrm{mg} / \mathrm{kg}\end{array}$ & $\begin{array}{l}\text { Acute neurotoxicity: } \\
\text { NOAEL for rats }-10 \mathrm{mg} / \mathrm{kg} \\
\text { Subchronic neurotoxicity: } \\
\text { NOAEL for rats }-200 \mathrm{ppm}(14.8 \mathrm{mg} / \\
\mathrm{kg}) \text {, based on weight loss and gain at } \\
800 \mathrm{ppm}(59.7 \mathrm{mg} / \mathrm{kg}) \\
\text { Neurotoxicity for offspring development: } \\
\text { NOAEL by maternal toxicity }-10 \mathrm{mg} / \\
\mathrm{kg} \text {; NOAEL by neurotoxic effects on } \\
\text { the development of offspring }-2.5 \mathrm{mg} / \mathrm{kg}\end{array}$ \\
\hline
\end{tabular}

Note. ${ }^{*} N O A E L-$ no observed adverse effect level/dose level at which damaging effects are observed, ${ }^{* *} N O E L-$ no observed effect level/dose level at which toxic effects are observed (inactive dose level).

observed in experimental animals at different times. The death of the animals was noted on the $4^{\text {th }}, 6^{\text {th }}$ and $14^{\text {th }}$ days of the experiment. According to the results of the study the drug's $\mathrm{LD}_{50}$ was established at the level of $500 \mathrm{mg} / \mathrm{kg}$.
According to literature data, determined parameters of toximetry at single oral administration in rats were: $\mathrm{LD}_{50}$ of emamectin benzoate - $67 \mathrm{mg} / \mathrm{kg}, \mathrm{LD}_{50}$ of acetamiprid $140 \mathrm{mg} / \mathrm{kg}[6,7]$. 
Contents of active substances in the studied preparation: emamectin benzoate $-10 \%$, acetamiprid $-15 \%$. Taking into account that other components of the drug are not limiting in its toxicological evaluation, we can assume that $25 \%$, which falls on the content of active substances in the drug, determines its toxicity $\left(\mathrm{LD}_{50}-500 \mathrm{mg} / \mathrm{kg}\right)$. The sum of the ratios of the amounts of each active substance in the preparation to their $\mathrm{LD}_{50}$ was $32.05 \%$, which indicates a clearly expressed potentiation of the combined toxic effect of the preparation with a potency factor of 3.12 .

In the next stage of the study, we assessed the potential combined (inhalation and dermal) effects of emamectin benzoate and acetamiprid on workers using a predictive risk assessment model [5].

Exposure calculations algorithm for Emiprid, WG took into account the following: production process step (mixing/filling and spraying) treatment method and sprayer type, formulation type (water soluble granules), container capacity/ outlet diameter ( $101 / 63 \mathrm{~mm})$, application dose of formulation/application volume $(0.25 \mathrm{~kg} /$ ha/300 1/ha); concentration of active substances in the formulation, availability of personal protective equipment (PPE).

According to literature data [6] dermal absorption of emamectin benzoate from preparative forms (solid formulations) is $1 \%$, from working solutions $-2 \%$. In justifying the value of the AOEL of emamectin benzoate, we used the ineffective level established in a chronic experiment (14 weeks) in dogs with (NOAEL of $0.25 \mathrm{mg} /$ $\mathrm{kg}$ ), a safety factor (SF) of 100 , an additional uncertainty factor of 5 (considering the severity of effects), and an oral absorption factor of $55 \%$ : $\mathrm{AOEL}=0.0003 \mathrm{mg} / \mathrm{kg}[6]$.

The dermal absorption of acetamiprid is $33.7 \%$ (concentrated formulation solutions) and $15.9 \%$ for ready-to-use solutions [7]. In justi- fying the AOEL value of acetamiprid, the results obtained in a neurotoxicity experiment on rats $($ NOEL $-2.5 \mathrm{mg} / \mathrm{kg})$ and $\mathrm{CP}-100$ were used: $\mathrm{AOEL}=0.025 \mathrm{mg} / \mathrm{kg}[7]$.

Absorbed dose of substances at inhalation ingestion was taken as $100 \%$ of maximum exposure dose.

Assessment of working conditions was performed according to exposure index (E), which is calculated as a ratio of total absorbed dose to permissible exposure level for an operator (AOEL). The risk is considered acceptable if $\mathrm{E} \leq 1$.

Exposure and absorbed dose calculations are shown in Table 3.

The data in Table 3 show that the total risk of inhalation exposure to active substances is 2.72 . Taking into account the potency factor of 3.12 , the risk of inhalation exposure exceeds the permissible 5.84 times, which requires appropriate management decisions aimed at ensuring a high level of human health protection.

The use of personal respiratory protection gear - universal respirators $67 \mathrm{~A}$, RU-60MA type and others with protection factor of 0,05 $(95 \%)$ will allow to decrease inhalation doses of emamectin benzoate and acetamiprid to values 0,00004 and $0,0006 \mathrm{mg} / \mathrm{kg}$ respectively.

At these values, the degree of risk of inhalation exposure to substances, taking into account the possible potentiation of their combined effect, is acceptable, since it is within the range of acceptable values and is 0.135 .

Thus, taking into account the potency factor in general characteristics of risk of combined and complex exposure to a mixed insecticide composition increases the effectiveness of assessment of working conditions and determines the plan of measures to reduce risk in making and implementing management decisions.

To ensure occupational safety and industrial hygiene at work with preparation «Emipride, WG» it is necessary to follow requirements of the 
Potential risk of effects of emamectin benzoate and acetamiprid on workers whenapplying Emipride, WG by boom spraying (POEM model)

Indicator

Value for active substances

\begin{tabular}{|l|}
\hline \multicolumn{1}{|c|}{ At the mixing/filling stage: $D$} \\
\hline $\begin{array}{l}\text { Levels of contamination of the skin of the hands, mg of active } \\
\text { sub/day }\end{array}$ \\
\hline Use of protection \\
\hline Absorption, $\%$ \\
\hline Dermal exposure to formulation, $\mathrm{mg} / \mathrm{day}$ \\
\hline
\end{tabular}

Inhalation exposure

Inhalation exposure, $\mathrm{mg} /$ day

Use of protection

Absorption, \%

Absorbed inhalation dose, mg/day

At the stage of spraying: Dermal exposure

Application volume, $1 /$ ha

Volume of surface contamination, $\mathrm{ml} / \mathrm{h}$

Total dermal exposure to spray, $\mathrm{ml} /$ day

Absorbed dose, mg/day

ermal exposure

\begin{tabular}{|l|l|}
7,15 & 10,725 \\
Gloves \\
\hline \multicolumn{3}{|c|}{1} \\
0,0715 & 0,10725 \\
\hline
\end{tabular}

Inhalation exposure

\begin{tabular}{|l|l|}
\hline 0,04475 & 0,067125 \\
\hline \multicolumn{3}{|c|}{-100} \\
\hline 0,04475 & 0,067125 \\
\hline
\end{tabular}

\begin{tabular}{|c|c|}
\hline \multicolumn{2}{|c|}{ Value for active substances } \\
\hline emamectin benzoate & acetamiprid \\
\hline
\end{tabular}

\begin{tabular}{|c|c|c|}
\hline \multicolumn{3}{|c|}{ Inhalation exposure } \\
\hline Inhalation exposure to working solution, $\mathrm{ml} / \mathrm{h}$ & \multicolumn{2}{|c|}{0,01} \\
\hline Inhalation exposure to active sub., $\mathrm{mg} /$ day & 0,005 & 0,0075 \\
\hline Absorption, $\%$ & \multicolumn{2}{|c|}{100} \\
\hline Absorbed inhalation dose, mg/day & 0,005 & 0,0075 \\
\hline Total absorbed dose mg/day & 0,061215 & 0,1656 \\
\hline Body weight of operator, $\mathrm{kg}$ & \multicolumn{2}{|c|}{60} \\
\hline Total absorbed inhalation/dermal dose, $\mathrm{mg} / \mathrm{kg}$ bw / day & $0,0008 / 0,0002$ & $0,0012 / 0,0015$ \\
\hline \multicolumn{3}{|c|}{ Risk assessment } \\
\hline AOEL, мг/кг & 0,0003 & 0,025 \\
\hline $\mathrm{E}_{\text {inhal }}=\mathrm{I}_{\text {adsorb }}: \mathrm{AOEL}$ & $0,0008: 0,0003=2,67$ & $0,0012: 0,025=0,05$ \\
\hline $\mathrm{E}_{\text {derm }}=\mathrm{D}_{\text {absorb }}: \mathrm{AOEL}$ & $0,0002: 0,0003=0,67$ & $0,0015: 0,025=0,06$ \\
\hline $\mathrm{E}_{\text {total }}=\mathrm{E}_{\text {inhal }}+\mathrm{E}_{\text {derm }}$ & 3,34 & 0,11 \\
\hline
\end{tabular}


developed instruction on safe application and to adhere to the conventional requirements of occupational safety and health at work with pesticides.

\section{Conclusions}

1. The prospect of combinations of active substances in pesticide formulations poses a threat of possible potentiation as one of the most dangerous types of combined effect on the organism.

2. Using the example of mixed pesticide composition on the basis of insecticides emamectin benzoate (chemical class of compounds avermectins) and acetamiprid (chemical class of compounds - neonicotinoids) the type of

\section{References}

1. Anderson and Meade. (2014), «Potential Health Effects Associated with Dermal Exposure to Occupational Chemicals", Environmental Health Insights, 8 (S1), 51-62, https://doi.org/10.4137/ EHI.S15258.

2. Kundiiev Yu. I. and Nahorna A. M. (2006), Occupational health in Ukraine. Epidemiological analysis, VD "Avicena", Kyiv, Ukraine, 316 p.

3. Nahorna A. M., Varyvonchyk D. V., Sokolova M. P. and Kononova I. G. (2019), "Epidemiological research and development of occupational diseases prevention programs among employees", in Naukovi zdobutky z medytsyny pratsi. Istoriia ta suchasnist [Scientific achievements in occupational health. History and modernity], Trakhtenberg I. M. and Chernyuk V. I. (Ed.), VD "Avicena», Kyiv, Ukraine, 166-221.

4. Vavrinevych O. P. (2015), «Hygienic estimation of potential combined risk of mixed fungicide harmful effects on workers", Ukrainian Journal of Occupational Health, 1 (42), 58-66. https://doi.org/10.33573/ ujoh2015.01.058. their combined toxic action has been defined, which is characterized by clearly marked effect of potentiation, and when taking it into account in the hazard identification by prognostic risk evaluation model, inhalation effect of active substances exceeded the acceptable level by almost 6 times.

3 . The necessity of taking into account potency factors in the study of working conditions with the use of combined preparations based on active substances with a similar orientation of toxic effects has been proved, which will increase the accuracy and reliability of the results of occupational risk assessment and will contribute to the development of preventive measures to prevent the harmful effects of pesticides on the body of workers.

5. Martin A. D. (1990), "A predictive model for the assessment of dermal exposure to pesticides", in Prediction of Percutaneous Penetration. Methods, Measurements, Modelling, Scott R. C., Guy R. H., Hadgraft J. (Ed.), IBC Technical Services Ltd, Southampton, Hampshine, UK, 273-278.

6. European Food Safety Authority (2012), "Conclusion on the peer review of the pesticide risk assessment of the active substance emamectin", EFSA Journal, 10 (11), 2955, 89. https://doi. org/10.2903/j.efsa.2012.2955.

7. European Food Safety Authority (2016), "Conclusion on the peer review of the pesticide risk assessment of the active substance acetamiprid", EFSA Journal, 14 (11), 4610, 26. https://doi. org/10.2903/j.efsa.2016.4610.

8. Emamectin benzoate (2010). Human Health and Ecological Risk Assessment. Final Report. URL: https://www.fs.fed.us/foresthealth/pesticide/ pdfs/052-23-03b_Emamectin-benzoate.pdf. (date of application: 25.08.2021).

9. Pesticide residues in food (2011). Joint FAO/ WHO Meeting on Pesticide Residues. Evaluation 2011. Part II - Toxicology. Acetamiprid. 3-92. 
ISSN 2223-6775, Ukrainian Journal of Occupational Health, 2021, 17 (3), 151-159

\section{ORCID ID of co-authors and their contributions:}

Yastrub T. A. (ORCID ID 0000-0002-5084-3773) - concept formation and research methodology, definition of goals, tasks and methods of the research, review of the literature on the topic of the research, analysis and interpretation of the results analysis and interpretation of the results of the research, formation of the conclusions, writing the article;

Dontsova D. A. (ORCID ID 0000-0003-3676-1672) - completion of toxicological research, statistical processing of obtained results.

Information about sources of financing of the research: the research has been carried out on the topic «Quantitative determination of percutaneous absorption in optimization of models of risk assessment of adverse effects of pesticides on workers», No. of state registration 0120 U100753.

Received: August 5, 2021

Accepted for publication: September 9, 2021

Contact Person: Yastrub Tetyana, Laboratory of Pesticide Toxicology and Occupational Hygiene, State Institution «Kundiiev Institute of Occupational Health of the National Academy of Medical Sciences of Ukraine», 75, Saksaganskogo str, Kyiv, 01033. Tel.: + 380442894274. 